\title{
Economic-Geographical Aspects of Competitiveness and Positioninng of Countries And Regions
}

\author{
Rubtzov V.A.
}

Kazan Federal University, Institute of Management, Economics and Finance, Kazan, 420008, Russia

Rozhko M.V

Kazan Federal University, Institute of Management, Economics and Finance, Kazan, 420008, Russia

Gabdrakhmanov N.K.

Kazan Federal University, Institute of Management, Economics and Finance, Kazan, 420008, Russia

Pratchenko O.V.

Kazan Federal University, Institute of Language, 420008, Kazan, Russia

Trofimov A.M.

Kazan Federal University, Institute of Management, Economics and Finance, Kazan, 420008, Russia

\section{Doi:10.5901/mjss.2015.v6n3p95}

\section{Abstract}

At present, the increased competition between countries and regions made the problem of study of competitiveness and positioning of regions in the system of the world and national economy relevant. This problem becomes even more important in conditions of the development of globalization and transition of countries to the post-industrial stage of development. All this led to the necessity to find ways to assess the competitiveness and the necessity for deeper analysis of the concept of competitiveness. Competitiveness of countries, regions and other territorial entities should be considered in mutual balance of all the principles of socio-economic development by a range of indicators of the following subsystems: population, economy, infrastructure, environment.

Keywords: competitiveness, positioning, region, country, socio-economic development.

\section{Introduction}

The process of globalization increased competition between countries and regions for a) foreign investments, b) innovation and c) new technologies. In this regard, the role of competitiveness of countries and their positioning in the global economy increased. Special schools of the theory of competitiveness appeared, the role and importance of some sciences that provide research and trend of the status of some countries and regions and their role in the world economic system and national security, increased. New terms that provide the practical use of new production methods in conditions of post-industrial development appeared. In this connection, the role and importance of social-economic geography which the representatives of the American School of competitiveness M. Porter [1] and M. Enright [2] "rediscovered" in the $80-90$ s of the $20^{\text {th }}$ century, increased. This is about the new scientific "stream" in the regional economy connected with the appearance of the term "cluster» (Porter) and "regional cluster» (Enright).

Before solving the problems of competitiveness (CSI) and positioning, it is necessary to analyze how they are discussed in the press, and especially, in Russia.

In recent years there were a lot of works on this topic $[3,4,5,6]$.

Historically, the concept of competitiveness is based on the theory of use of comparative advantages of national economies in the international division of labor (cheap labor, rich natural resources, favorable geographic, climatic, infrastructural factors, etc.) in relation to the countries where there are no such benefits. 
However, it is also true that the concept of competitiveness is changing dynamically; it is not once and forever established. The fact is that in the process of development the new competitive conditions that change the vector of competition from the use of comparative national advantages to the use of fast-changing competitive advantages based on scientific-technical achievements, innovations at all stages from creation of the product to its promotion from producer to consumer, are established and become up.

"The comparative advantages are given to the country by nature, they are static and not eternal and are not reproducible.

Competitive advantages are dynamic, they are linked to innovation, development of human capital, intelligence, and they are endless by nature."

It is not possible to oppose these benefits. It is necessary to understand them very clearly. Integration in one country of all benefits increases its competitiveness in the global economic space. In this regard, a dramatic decline of the level of higher and secondary vocational education in the country causes concern.

Currently, there is a technique of IEF (International Economic Forum is highlighted by research results in intercountry competitiveness). It allows every country to develop a composite index of competitiveness measured on the basis of macroeconomic indicators that are especially important for economic growth and that are correlated with it. The scheme of the main complex factors of competitiveness of the country is developed. There are eight of them; their index (in \%) characteristics are also given.

The concept of competitiveness is definitely not complete and it has a bias towards economic positions. On the one hand, it is clear: the economic aspect is really the dominant in determination of the process of socio-economic development of the region. On the other hand, the role of the environmental aspect is definitely not taken into account. It is given only "tangentially." However, in some cases, in the assessment of the socio-economic development of the region the environmental component plays a major role. There are other shortcomings in the concept of competitiveness as well.

In the post-industrial phase of social development such things as quality of life of population, statement of "mission" of the region, "challenges" of the environment in relation both to the region as a whole, as well as to its parts, become especially important. Thus, trends of competitive and positioning still require deep discussion.

From the above it follows that the competitiveness of the region should be considered by the following major subsystems: population, economy, infrastructure and ecology. There is no doubt that the main aim of any concept connected with the development of the region, its positioning and assessment of its competitiveness should be connected with constant increase of quality of life $[7,8,9]$.

\section{Method}

The concept of competitiveness should be organized with inter-balance of all principles of socio-economic development of the region.

The analysis of the literature shows that, indeed, the economic aspect of competitiveness is a leading and decisive. However, the fact that such components as territorial (geographical), ecological-natural, social, etc., should be taken into account in the conceptualization of competitiveness, is also important [10].

So, first we define the concept of the determinant of the conception from the economic point of view: the state of demand, related and supporting industries, sustainable strategy, stable structure and rivalry.

Competitiveness of countries and regions could be considered within the frames of the scheme of principles and indicators grouped into 3 main blocks (Fig. 1).

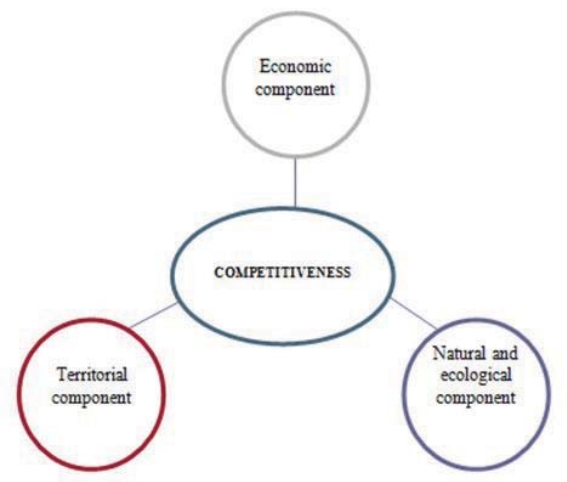

Fig 1. Scheme of competitiveness components 
In the study of regional competitiveness it is also possible to take into account additional parameters [11, 12].

Thus, in general the competitiveness index can be described by the formula:

$$
I_{\text {competitivness }}=I_{\text {economic }}+I_{\text {territorial }}+I_{\text {ecological }}+\varepsilon \text {; }
$$

where $\varepsilon$ - additional parameters.

\section{Result}

To assess the competitive it is necessary to learn the constituent components of every block of the described scheme (Table 1).

Table 1. Indicators of the blocks of the scheme of competitiveness components

\begin{tabular}{|c|c|c|}
\hline Economic component & Territorial component & Nature-environment component \\
\hline Role of the state and management & $\begin{array}{l}\text { "Challenges" of the region (its mission and } \\
\text { possibilities) }\end{array}$ & $\begin{array}{l}\text { Stability of the territory (areas of risk, } \\
\text { critical, etc.) }\end{array}$ \\
\hline New demographic model & Nature-environment potential of the territory & $\begin{array}{l}\text { Emergency situations, catastrophes, crisis } \\
\text { state }\end{array}$ \\
\hline Gross domestic product & Social-economic situation & Recreation capacity of the territory \\
\hline $\begin{array}{l}\text { Business efficiency. Investment. } \\
\text { Presence of "growth points }\end{array}$ & $\begin{array}{l}\text { Balance of territorial development (marginal } \\
\text { and other zones and areas) }\end{array}$ & $\begin{array}{l}\text { Nature reserves, wildlife reserves, nature } \\
\text { protection sites }\end{array}$ \\
\hline Innovation growth & Territoriality and positional principle & \\
\hline Information-technical sphere & $\begin{array}{l}\text { Diffusion of innovations, security of } \\
\text { development of the region, risks }\end{array}$ & \\
\hline \multirow[t]{2}{*}{ Creative economic industries } & $\begin{array}{l}\text { Situational factors (waves and cycles of } \\
\text { development, failures, etc.) }\end{array}$ & \\
\hline & Formation of "growth points" & \\
\hline
\end{tabular}

As far as the components of the first economic (social-economic) block were described in detail in the previous part, we will focus on the characteristics of the second and third blocks.

Territorial (spatial, geographical) component forms the second block.

1. "Challenges" of the region (its mission and possibilities).

Strategy should take into account the challenges to development. Challenge is understood as the perceived probable advanced condition of the external and internal state of the environment of the region that causes serious complications in the development and requires an anticipating reaction in the planned period.

2. Nature-environment potential of the territory (NEPT).

The economic-geographical essence of NEPT is understood as the cumulative performance of its natural resources as the means of production and consumer goods expressed in their public use value.

3. Social-economic situation.

Social-economic situation of the region in the territorial block involves consideration of the attitude towards the developed and developing regions or - more precisely - the attitude to the regions with the primitive, agrarian, industrial, service and information economy, as well as to the poles of growth and financial-information centers and the choice of the optimal model of social organization and economy.

4. Balance of territorial development (marginal and other zones and areas).

The idea of spatial balance intersects with the concept of "harmonious development of the socio-economic region" [13]. Harmonization of the development process means to achieve such level of sensitivity of the economy, at which the public costs for recovery are optimal or close to them.

5. Territoriality and positional principle.

The concept "territory", "territoriality" are used in the processes of the regional analysis in two ways: as a special type of resource and as the space organized in a special way. It includes not only the territory itself, but also many other natural, social and economic elements that fill the area, apart from which its objective, socially significant estimate is impossible.

6. Diffusion of innovations, security of development of the region, risks.

Innovation is the purposeful change that brings in the introductions, new relatively stable elements: tangible as well as intangible, social, etc., into environment (company, settlement, region, society, etc.). Diffusion of 
innovations is constantly in spotlight because of the key role of this process in long-term socio-economic shifts.

7. Situational factors (waves and cycles of development, failures, etc.).

Public (social-economic) development is always wavy. Not the study of nature of cyclical changes - but of nature of cycles themselves and their deployment in time, that is the dynamic aspect of the theory of equilibrium - is more important for modeling the process of social-economic changes.

8. Formation of "growth points".

"Growth points" of Peru are a consequence of the universal process of "concentration and dispersion" which determines the appearance of points in space that attract the flows of matter, energy and information. They are well-known attractors. The concept "center - periphery" appeared exactly on this basis [14].

Nature-environment component forms the third block.

1. Stability of the territory (areas of risk, critical, etc.).

The problem of stability of the territory is one of the major scientific directions which is in the stage of development and improvement. Its appearance was caused by the necessity of making the estimates of natural, social, economic and ecological state of territorial systems (the integrated assessment of the potential of the area as and internal aspect of sustainability) for the maximum possible use of them, their quantitative characteristics and the restrictive ultimate load on the territory.

2. Emergency situations, catastrophes, crisis state.

Study of occurring or already occurred emergencies, natural or technological disasters or crisis manifestations is necessary in assessing the competitiveness of the region, especially in terms of its natural-ecological component.

3. Recreation capacity of the territory.

Recreation capacity is determined on the basis of taking into account a number of factors: social and psychological; environmental; technical.

4. Nature reserves, wildlife reserves, nature protection sites.

Assessment of the degree of original preservation of the territory - in relation to its current state - play an important role in competitiveness of the region. Comparison of the current state of the territory with its original (conditionally) state can give such assessment. Therefore, development of a network of protected areas is one of the priorities of environmental protection.

\section{Conclusion}

Taking into account that competitiveness should be considered comprehensively, it was suggested to consider the competitiveness in three main blocks: economic, territorial, natural and ecological. However, it should be noted that even these three blocks cannot develop the concept of competitiveness to the full.

These blocks indicate various aspects of competitiveness. But for practical purposes, it is necessary to extend the consideration of competitiveness to the level of individual indicators in order to solve practical problems.

\section{References}

Porter M.E. The Competitive Advantage of Nations //Harvard Buisness Review. March - April, 1990. - P.73-93.

Enright M.I. The Geographical Scope of Competitive Advantage //Stuck in the Region? Changing scales for regional identity. - Utrecht, 1993. - P.87- 102.

Huggins, R., Izushi, H., Prokop, D., Thompson, P. Regional evolution and waves of growth: A knowledge-based perspective // Expert Systems with Applications. 41(12), 2014, pp. 5573-5586.

Zhang, K.H. How does foreign direct investment affect industrial competitiveness? Evidence from China // China Economic Review. 30, 2014, pp. 530-539.

Ženka, J., Novotný, J., Csank, P. Regional Competitiveness in Central European Countries: In Search of a Useful Conceptual Framework // European Planning Studies. 22 (1), 2014, pp. 164-183.

Bagautdinova, N., I. Gafurov, N., Kalenskaya and A. Novenkova, 2012. The regional development strategy based on territorial marketing (the case of Russia) World Applied Sciences Journal, 18. SPL.ISSUE., 18, pp. 179-184.

Denmukhametov, R.R. and O.V. Zjablova. Geodemographic situation in the Republic of Tatarstan. World Applied Sciences Journal. Volume 30, Issue 11, 2014, pp. 1684-1688.

Gabdrakhmanov N.K. and M.V. Rozhko Positioning of Volga Federal District Regions by Demographic Situation Index // World Applied 
Sciences Journal, Volume 30 Number 6, 2014. pp. 792-795.

Gabdrakhmanov, N.K. and V.A. Rubtzov, 2014. Geodemographic Polarization Processes: Municipal Level (The Case of the Kukmorsky Municipal District of the Republic of Tatarstan). World Applied Sciences Journal, 30(10), pp. 1317-1320.

Komarova, V.N., Zjablova, O.V., Denmukhametov, R.R. An infrastructure factor in regional competitiveness // Mediterranean Journal of Social Sciences. 5 (18 SPEC. ISSUE), 2014, pp. 355-360.

Gabdrakhmanov N.K., Rubtzov V.A., Shabalina S.A., Rozhko M.V., Kucheryavenko D.Z The role of territorial organization of cities in the touristic attraction of the region on the example of the Republic of Tatarstan // Life Science Journal 2014;11(11), pp. 451-455.

Mingaleva, Z., Bunakov, O. Innovative ways of using the tourist potential as the basis of territories development // Life Science Journal. Volume 11, Issue 6 SPEC. ISSUE, 2014, pp. 315-317.

Sus E. Pojecie i dziedziny harmonizawania roswjn spelecznocospodarczego regionu //Pr.nank.Wroclawn, 1984. \# 286. pp.7-14.

Wallerstain I. Modern World - System. Nr., 1989. Vol.2. pp.128-189. 